\title{
Evaluation of using Different Adjuvants used for Preparation of Staphylococcus aureus Mastitis Vaccine on The Immune Response Ebtsam E.Z. Kotb ${ }^{1}$, Amal M. EL Sawah ${ }^{2}$, Laila E. Kortam ${ }^{1}$, Ola A. Abd El Fattah ${ }^{3}$, Waleed M. Barghooth ${ }^{2}$ \\ ${ }^{1}$ Animal Reproduction Research Institute (ARRI), Agricultural Research Center (ARC), Egypt. ${ }^{2}$ Central Laboratory for Evaluation of Veterinary Biologics, Agricultural Research Center (ARC), Egypt. \\ ${ }^{3}$ Animal Health Research Institute (AHRI), Giza lab., Agricultural Research Center (ARC), Egypt. "Corresponding Author, Ebtsam E.Z. Kotb, E-mail: dekotb@yahoo.com
}

\begin{abstract}
Staphylococcus aureus ( $S$. aureus) was the most prevalent bacteria recorded from clinical and subclinical mastitis. The main objective of the present work is to prepare and evaluate the effectiveness of locally prepared inactivated $S$. aureus vaccine using different adjuvants Montanide ISA-206, Montanide ISA-70 and alum hydroxide gel for detection of cellular and humeral immune responses. Seventy dairy heifers in the last trimester of gestation divided into (5) groups. Twenty pregnant cows in three groups (G1, G2, and G3) were inoculated intramuscularly with the prepared vaccines four weeks prior to calving then a booster dose at two weeks pre-expected calving. The animals in remaining groups (G4 and G5) were considered as control and safety test respectively. Serum samples from vaccinated and non-vaccinated cows were collected at the 1 st and 2 nd immunization then at $0,1,2,3$ months and $(7,10,14)$ days post calving and vaccination and evaluated immunologically using ELISA and Lymphocyte transformation assay, respectively. The results revealed that a progressive increase of immune response in the vaccinated groups (G1 and G2) than that of the third and control groups. These results could be indicated the safety and effectiveness of the Montanide ISA-206, ISA70 vaccines than alum adjuvant vaccine that reduce the incidence and severity of clinical cases of mastitis. Hence, further studies should be done to elucidate the possibility of field application.
\end{abstract}

Keywords: Adjuvant, mastitis, Staphylococcus aureus, Vaccine.

\section{Original Article:}

DOI:https://dx.doi.org/10.21608/javs.2021.1 $\underline{40065}$

Received :13 October, 2020.

Accepted :27 December, 2020.

Published in January, 2021.

This is an open access article under the term of the Creative Commons Attribution 4.0 (CCBY) International License. To view a copy of this license, visit:

http://creativecommons.org/licenses/by/4.0/

\section{INTRODUCTION}

Bovine mastitis is one of the most frequent and costly infectious diseases present in all dairy operations worldwide. Several microorganisms have been described to produce bovine mastitis but most cases are caused by different species of Streptococcus, Staphylococcus and coliform bacteria (Blowey and Edmondson, 2010). Staphylococcus aureus is considered the most contagious mastitis pathogen of dairy cattle in most countries and usually related to subclinical or chronic mastitis. The major reservoir for infection is the udder and transmission occurs during milking time (Middleton et al., 2006). Therefore, control has been focused on milking hygiene and dry cow therapy. However, the cure rate of antibiotic treatment for $S$. aureus mastitis pathogen is very low. Excessive use of antibiotics for $S$. aureus mastitis treatment and other infectious diseases in domestic animals have induced the emergence of highly resistant bacterial strains to antibacterial drugs, making more difficult to control $S$. aureus mastitis (San Martín et al., 2002).

During the last years, vaccination has been introduced to combat $S$. aureus bovine mastitis (Pereira et al., 2011, Schukken et al., 2014 and Bradley et al., 2015). Vaccination against mastitis pathogens is a good control strategy and can be used as a complement of traditional control programs based upon hygiene and management. Traditional S. aureus mastitis vaccines have included killed or attenuated bacteria, toxoids and cell wall extracts from selected laboratory or field strains (Watson, 1992 and Watson et al., 1996) and Ismail (2017). Numerous recent attempts to develop $S$. aureus vaccine including whole organism, DNA encoding clumping factor A, live attenuated $S$. aureus, capsular polysaccharide CPS- 
protein conjugate and DNA recombinant $S$. aureus protein vaccines (Pereira et al., 2011).

Adjuvants have been defined as agents added to vaccine formulations in order to trigger the immunogenicity of antigens and induce protection against infection. Past approaches of vaccine formulation with adjuvants were focused on singletype adjuvants such as alum. Alum salts are relatively weak adjuvants and rarely induce cellular immune responses but, these slow down the rate of release of the antigen and also increase the duration of antigen interaction with the immune system, thus enhancing the humoral immune response against the antigen (Lindblad 2004). However, new vaccine targets require the induction of well-defined CMI in addition to high titer of antibody. Consequently, new immunostimulant adjuvants in vaccine formulations are needed in order to stimulate robust immune responses including humoral immunity and CMI (Lee and Nguyen, 2015).

Montanide is a family of oil-based adjuvants that have been used in experimental vaccines. Emulsions of montanide are composed of metabolizable sequence-based oil with a mannide mono-oliate emulsifier shown to induce high antibody titer and cytotoxic T-lymphocytes CTL responses in a variety of animal species. (Teena et al., 2013).

The objective of this study was the preparation of $S$. aureus vaccine from isolated field strain by using different types of adjuvants and detection of cellular and humeral immune responses to control mastitis in dairy farm and prevent of bulky milk loss.

\section{MATERIALS AND METHODS}

\section{Animals and samples}

A total of 400 quarter milk samples (QMS) were collected from 100 Holstein cows reared in a semi-intensive system herd suffered from clinical and subclinical mastitis were used in the present study. Milk samples were collected in sterilized tubes after disposal of the three first milk streams and applying 70 $\%$ alcohol on the external teat skin. Milk samples transported in an icebox to laboratory of the Animal Reproductive Research Institute (Giza).

Each sample was subjected to California mastitis test (CMT) according to Schalm and Noorlander (1957) and the results were interpreted as suggested by Ferronatto et al. (2018) and Hoque $\boldsymbol{e t}$ al. (2015) classified as follows: negative (score 0), trace (score 1), weakly positive (score 2), positive (score 3 ) and strongly positive (score 4).

Isolation and identification of Staphylococcus aureus Strain for Vaccine development

Isolation of $S$. aureus was attempted according to Thaker et al., (2013) with some modifications.
Enrichment of each milk sample was carried out in Peptone Water (PW) and enriched for $24 \mathrm{hrs}$ at $37^{\circ} \mathrm{C}$. After pre-enrichment, a loopful of inoculum was transferred to Baird Parker and Mannitol salt agar plates as a selective media then incubated for 48 hours at $37^{\circ} \mathrm{C}$.

Colonies suspected of being Staphylococci were initially identified by their colony morphology and Gram staining. The pure cultures were sub cultured on Nutrient agar and incubated for 24 hours at $37^{\circ} \mathrm{C}$ for further biochemical identifications. Catalase activity and coagulase tests were performed to distinguish catalase-negative Streptococcus spp. from catalasepositive, coagulase production by coagulase-positive Staphylococci was examined using the tube coagulation method. Quinn et al. (2003).

\section{Molecular characterization of Staphylococcus aureus using PCR}

All initially identified isolates were further confirmed by duplex PCR targeting 16S rRNA and nuc genes (nuc; Staphylococcus aureus thermonuclease gene) using genus specific oligoneucleotide primers as previously described by Wang et al. (2012). Finally, all isolates were stored in brain heart infusion broth with $15.0 \%$ glycerol at $-80{ }^{\circ} \mathrm{C}$ until further use. Bacterial investigation of $S$. aureus successfully isolated and confirmed was used for preparation of $S$. aureus vaccine.

\section{Adjutants and vaccine formulation \\ 1.1. Montanide ISA70 and ISA 206}

The oil-adjuvanted vaccine was prepared using a mineral oil (SEPPIC Montanide ISA-70, ISA- 206 SEPPIC Division Cosmetique-Pharmacie, and Paris, France) Montanide oils adjuvants were formulated as a water-in-oil emulsion. The antigens were mixed with the oil in Montanide ISA- $70(30 / 70)(\mathrm{v} / \mathrm{v})$ ratio while in Montanide ISA-206 (50/50) as recommended by the manufacturer.

\subsection{Alum adjuvant}

Aluminum Hydroxide $1 \%$ gel was used as adjuvant for the inactivated vaccine (Biowest France).

\section{Preparation of $S$. aureus vaccine}

It was prepared according to Opdebeeck and Norcross (1984). The Bacterin was prepared by growth of pure $S$. aureus strain isolated from mastitic milk samples on blood agar medium for 24 hours. The organisms were harvested from the surface of the medium by gentle agitation using sterile saline solution and glass beads, and then centrifuged at $17000 \mathrm{xg}$ for 15 minutes at $4^{\circ} \mathrm{C}$. The pellet was suspended in PBS (Phosphate Buffer Saline) (pH 7.6) and washed with sterile saline solution. The end product solution containing microorganisms was inactivated by suspension in $0.3 \%$ formalized saline. Antigen 
concentration was adjusted to $8 \times 10^{8} \mathrm{cfu} / \mathrm{ml}$. The bacterial antigen was mixed with adjuvants Montanide ${ }^{\circledR}$ ISA 206, Montanide ISA 70 and alum as recommended by the manufacturer.

\section{Vaccination of cattle}

Seventy (70) dairy heifers in the last trimester of gestation divided into (5) groups. Twenty pregnant cows in each group $(\mathrm{G} 1, \mathrm{G} 2, \mathrm{G} 3)$ were inoculated intramuscularly with $5 \mathrm{ml} / \mathrm{cow}$ of the prepared vaccine 4 weeks prior to calving then a booster dose of 5 $\mathrm{ml} /$ cow 2 weeks after the primary injection. (G1) was vaccinated by Staph vaccine with Montanide ISA-206, (G2) was vaccinated by Staph. vaccine with Montanide ISA-70 and (G3) vaccinated by staph vaccine with alum. While four and six cows in (G4\&G5) were kept as non-vaccinated control and safety groups respectively.

Blood samples were collected at 7, 10 and 14 days after first injection for lymphocyte proliferation activity using (MTT) and COMET assay. Pooled serum samples were collected at the $0,1,2$ - and 3-months post vaccination.

\section{Quality control testing of the prepared vaccine}

The prepared vaccine was test according to OIE, 2013 for sterility, safety and potency as a quality control tests.

\subsection{Sterility test}

Sterility test was done according to British veterinary pharmacopoeia (1993) to confirm the sterility in all production steps.

\subsection{Safety}

Six animals (G5) were inoculated with double dose of each vaccine (two animals for each vaccine). The inoculated animals were observed for 2 weeks after inoculation for development of any clinical signs.

5. Determination of immune response to the prepared vaccines by indirect enzyme-linked immunesorbent Assay (ELISA)

ELISA was performed as previously described by Leitner et al., (2000). Each serum sample was tested for $S$. aureus antibodies before immunization. In brief, 96-well immunoplates (Nunc-Immuno Plate Maxi SorbTM) were coated with killed sonicated $S$. aureus, as antigen and incubated 2 hours at $37^{\circ} \mathrm{C}$ and then overnight at $4^{\circ} \mathrm{C}$. The coating solution was then washed and the plates were blocked with bovine serum albumin $3 \%$ at $37^{\circ} \mathrm{C}$ for one hour. After washing the plates three times with PBS-Tween (PBS 0.1M pH 7.4, $0.5 \%$ Tween 20$)$, tested serum $(1: 200)$ was added in duplicate, incubated for $1 \mathrm{~h}$ at $37{ }^{\circ} \mathrm{C}$ then affinitypurified goat anti-Bovine $\operatorname{IgG}(\mathrm{g})$ chain peroxidase conjugate (1:2000) (KPL company) was added.
The bound antibodies were detected by adding TMB peroxidase substrate (Kirkegaard and Perry Laboratories). Plates were read in a microplate auto reader at $450 \mathrm{~nm}$. Negative serum samples from uninfected cows were used to calculate the cut-off value of the indirect ELISA. Cut-off = Mean of Negatives $+(3 \times$ standard deviation of Negatives). Samples was considered as positive if the OD values were higher than the cut-off value, otherwise, the sample was regarded as negative if the OD was below the cut-off value (Tong et al., 2014).

\section{Blood cell's DNA integrity using comet assay}

According to Singh et al. (1988) single cell gel electrophoresis assay (SCGE) was performed for simple evaluation of cellular DNA damage (under alkaline conditions). First, individual cells are mixed with low melting agarose before application to the OxiSelect Comet Slide.

These embedded cells are then treated with a lysis buffer and alkaline solution, which relaxes and denatures the DNA. Finally, the samples were electrophoresed in a horizontal chamber to separate intact DNA from damaged fragments. Following alkaline electrophoresis, the samples are dried, stained with ethidium bromide stain $12 \mathrm{ug} / \mathrm{ml}$, and visualized by epifluorescence microscopy. Under these conditions, the damaged DNA (containing cleavage and strand breaks) will migrate further than intact DNA and produce a "comet tail" shape (Figure 2A). Tail moment (arbitrary unit) $=$ Length of DNA migration (um) $\times$ percentage $(\%)$ of migrated DNA.

\section{Lymphocytes transformation assay}

Lymphocyte proliferation assay (LPA) measures the ability of lymphocytes to undergo clonal proliferation when stimulated by a foreign molecule, antigen or mitogen in vitro. Blood samples were taken during the experiment on heparin for separation of $\mathrm{T}$ lymphocyte by aseptically collection, centrifugation at $2500 \mathrm{rpm}$ at $4 \mathrm{C}^{\circ}$ for 30 minutes, the leukocytic layer transferred on to sterilized tissue culture tube, overlayed on ficol (1.077) in sterilized tissue culture tube, centrifuged at $4000 \mathrm{rpm}$ for 30 minutes at room temperature. The mononuclear interphase layer was taken for separation of T-lymphocyte for lymphocyte transformation assay using MTT reduction assay according to Chin et al. (2000).

\section{Statistical analysis}

All data were subjected to Statistical analysis according to Snedecor and Cochran (1982) and results were expressed as means \pm standered error SE. Differences between means in different groups were tested for significance using student $\mathrm{T}$ test as independent $\mathrm{T}$ test for all parameters. 


\section{Evaluation of using Different Adjuvants used for Preparation of ........}

\section{RESULTS}

One hundred dairy cows were examined for the presence of clinical and subclinical mastitis. The Incidence of clinical and subclinical mastitis in examined dairy cows and bacterial isolation from positive cases are shown in table (1), were 8\% (32/400) and $49.8 \%$ (199/400), respectively. On the other hand, S. aureus were found in $90.6 \%$ of the clinical mastitis (29/32) and in $70.4 \%$ of the subclinical mastitis samples $(140 / 199)$.

Regarding quality control of the prepared vaccines it was found that all of the prepared vaccines proved free from any contaminants (aerobic, anaerobic bacteria, fungi and mycoplasma). Also, they were found to be safe where no post vaccinal reaction was recorded on vaccinated animals.

As shown in table (2) and Fig (1) the antibody response in sera of vaccinated cows by Montanide ISA206 (G1) recorded the highest antibody titers present after the 2nd immunization till the third month after calving 3.264, 3.482, 2.866, 2.337 and 1.426. While (G
2) cows vaccinated by Montanide ISA-70 showed increase of antibody titers as 3.024, 3.203, 2.773, 2.189 and 1.370 in the same periods. Otherwise (G 3) vaccinated by alum registered low antibody titers $2.221,2.850,2.773,2.189$ and 1.163 . In contrary no increase in antibody titers was detected in the control group.

The results in (Table, 3 ) showed that the DNA damage was significantly increased in G3 in both comet percent and tail moment while in G1 and G2 showed significant increase in comet percent with nonsignificant increase in tail moment when compared with control group.

Table 1: Incidence of clinical and subclinical mastitis in examined dairy cows

\begin{tabular}{|c|c|c|c|c|c|c|c|c|}
\hline \multicolumn{5}{|c|}{ Clinical mastitis* } & \multicolumn{4}{|c|}{ Subclinical mastitis** } \\
\hline \multirow{2}{*}{$\begin{array}{l}\text { No. of } \\
\text { examined } \\
\text { quarters }\end{array}$} & \multicolumn{2}{|c|}{$\begin{array}{c}\text { QMS from } \\
\text { clinically infected } \\
\text { cows }\end{array}$} & \multicolumn{2}{|c|}{$\begin{array}{l}\text { Bacterial } \\
\text { pathogens } \\
\text { isolated }\end{array}$} & \multicolumn{2}{|c|}{$\begin{array}{l}\text { QMS from } \\
\text { apparently } \\
\text { healthy cows }\end{array}$} & \multicolumn{2}{|c|}{$\begin{array}{l}\text { Bacterial } \\
\text { pathogens } \\
\text { isolated }\end{array}$} \\
\hline & No. & $\%$ & No. & $\%$ & No. & $\%$ & No. & $\%$ \\
\hline 400 & 32 & 8 & 29 & 90.6 & 199 & 49.8 & 140 & 70.4 \\
\hline
\end{tabular}

* Hot, hard sensitive udder that is acute painful to the animal with changes in milk composition.

** No visible changes in appearance of udder and/or the milk but the milk samples were positive for (CMT).

Table 2: The mean serum Optical Density (OD) values in dairy cows vaccinated with inactivated $S$. aureus vaccines and control heifers measured by ELISA

\begin{tabular}{|c|c|c|c|c|c|c|c|}
\hline \multirow{2}{*}{\multicolumn{2}{|c|}{ Animal groups }} & \multirow{2}{*}{$\begin{array}{l}\text { 1st immunization } \\
\text { (4weeks pre- } \\
\text { expected calving) }\end{array}$} & \multirow{2}{*}{$\begin{array}{l}\text { 2nd immunization } \\
\text { ( } 2 \text { weeks pre- } \\
\text { expected calving) }\end{array}$} & \multicolumn{4}{|c|}{ Months after calving } \\
\hline & & & & 0 & 1 & 2 & 3 \\
\hline \multirow{3}{*}{$\begin{array}{c}\text { Vaccinated } \\
\text { groups }\end{array}$} & G 1 & 0.042 & 3.264 & 3.482 & 2.866 & 2.337 & 1.426 \\
\hline & G 2 & 0.411 & 3.024 & 3.203 & 2.773 & 2.189 & 1.370 \\
\hline & G 3 & 0.415 & 2.221 & 2.850 & 2.773 & 2.189 & 1.163 \\
\hline \multicolumn{2}{|c|}{ Control Group } & 0.433 & 0.421 & 0.445 & 0.411 & 0.453 & 0.427 \\
\hline
\end{tabular}

Cut off value $=0.44$. 


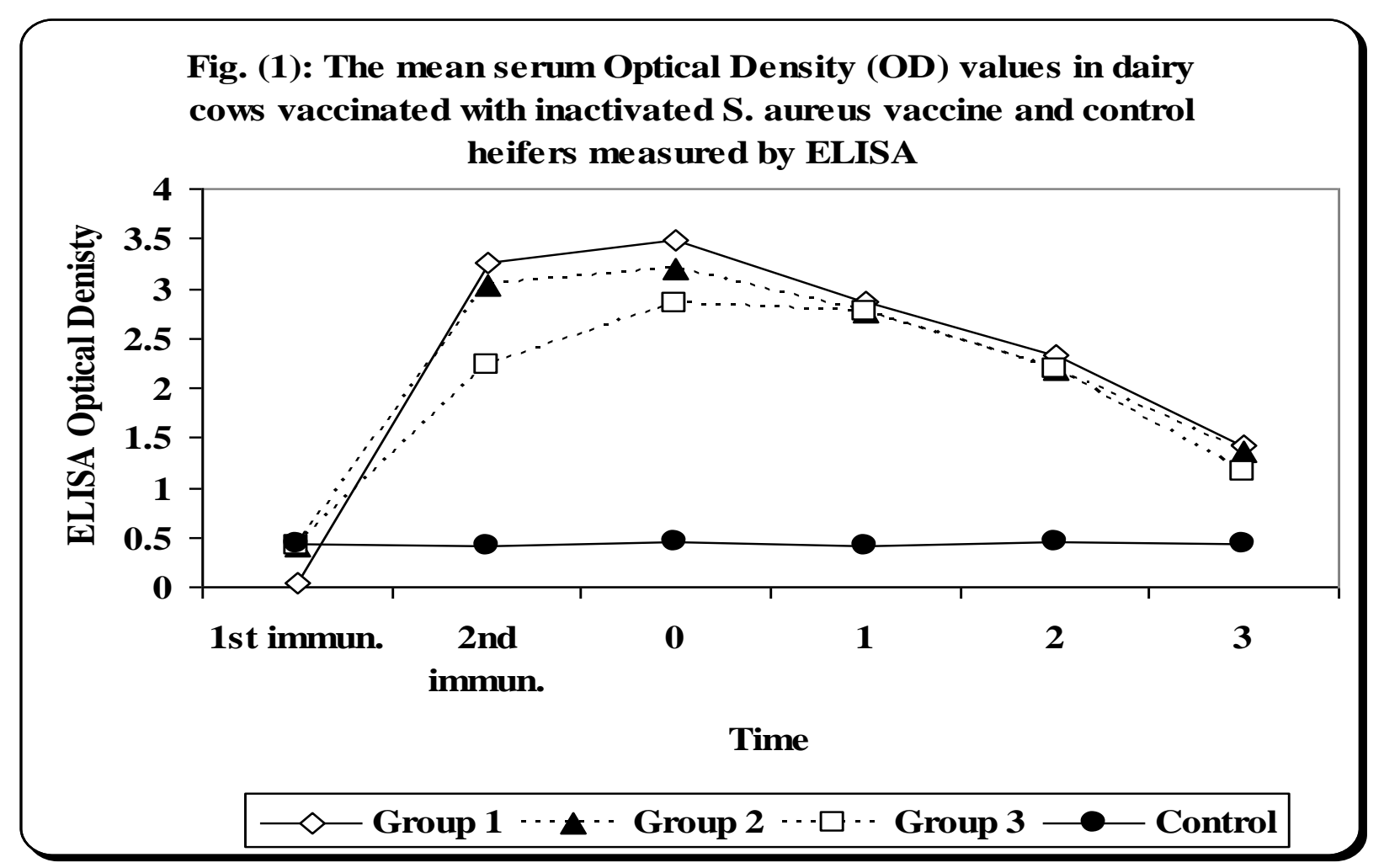

Fig. 1: ELISA antibody titers of vaccinated calves' groups and control group

N.B.

The first group (G1) vaccinated by Montanide ISA-206

The second group (G2) vaccinated by Montanide ISA-70

The third group (G3) vaccinated by alum

The fourth group (G4) as control

Table 3: The results of the prepared vaccines on blood cell integrity using comet assay in comparison with non-vaccinated

\begin{tabular}{|c|c|c|c|c|}
\hline Groups & $\begin{array}{c}\% \\
\text { Damage }\end{array}$ & $\begin{array}{l}\text { Tail } \\
\text { length }\end{array}$ & $\begin{array}{c}\% \\
\text { DNA } \\
\text { in tail }\end{array}$ & $\begin{array}{c}\text { Tail } \\
\text { movement }\end{array}$ \\
\hline \multirow[b]{2}{*}{ G1 } & 10.2 & 6.92 & 7.7 & 0.530 \\
\hline & $\begin{array}{c} \pm \\
0.14^{b}\end{array}$ & $\begin{array}{c} \pm \\
0.27\end{array}$ & $\begin{array}{c} \pm \\
0.092\end{array}$ & $\stackrel{ \pm}{ \pm .017^{\mathbf{b}}}$ \\
\hline \multirow[b]{2}{*}{$\mathrm{G} 2$} & 9.4 & 10.2 & 3.04 & 0.302 \\
\hline & $\begin{array}{c} \pm \\
0.26^{\mathbf{c}}\end{array}$ & $\begin{array}{c} \pm \\
0.62\end{array}$ & $\begin{array}{c} \pm \\
0.28\end{array}$ & $\frac{ \pm}{0.06^{d}}$ \\
\hline G3 & $\begin{array}{c}15.5 \\
\pm \\
1.4^{\mathrm{a}}\end{array}$ & $\begin{array}{c}6.64 \\
\pm \\
0.68\end{array}$ & $\begin{array}{c}7.8 \\
\pm \\
0.95\end{array}$ & $\begin{array}{c}0.601 \\
\pm \\
0.14^{\mathrm{a}}\end{array}$ \\
\hline $\begin{array}{l}\text { Control } \\
\text { group }\end{array}$ & $\begin{array}{c}7.4 \\
\pm \\
0.8^{d}\end{array}$ & $\begin{array}{c}7.85 \\
\pm \\
1.09\end{array}$ & $\begin{array}{c}5.04 \\
\pm \\
0.46\end{array}$ & $\begin{array}{c}0.39 \\
\pm \\
0.05^{\mathrm{c}}\end{array}$ \\
\hline
\end{tabular}

Means with different superscript letters in the same column are significantly different at $(\mathrm{p}<0.05)$. Fig. (2) A and B illustrate sever DNA damage in blood cells of cows vaccinated with $S$. auras vaccine by the comet assay. The increase in DNA damage was mostly evidenced by an increase of comet tail.
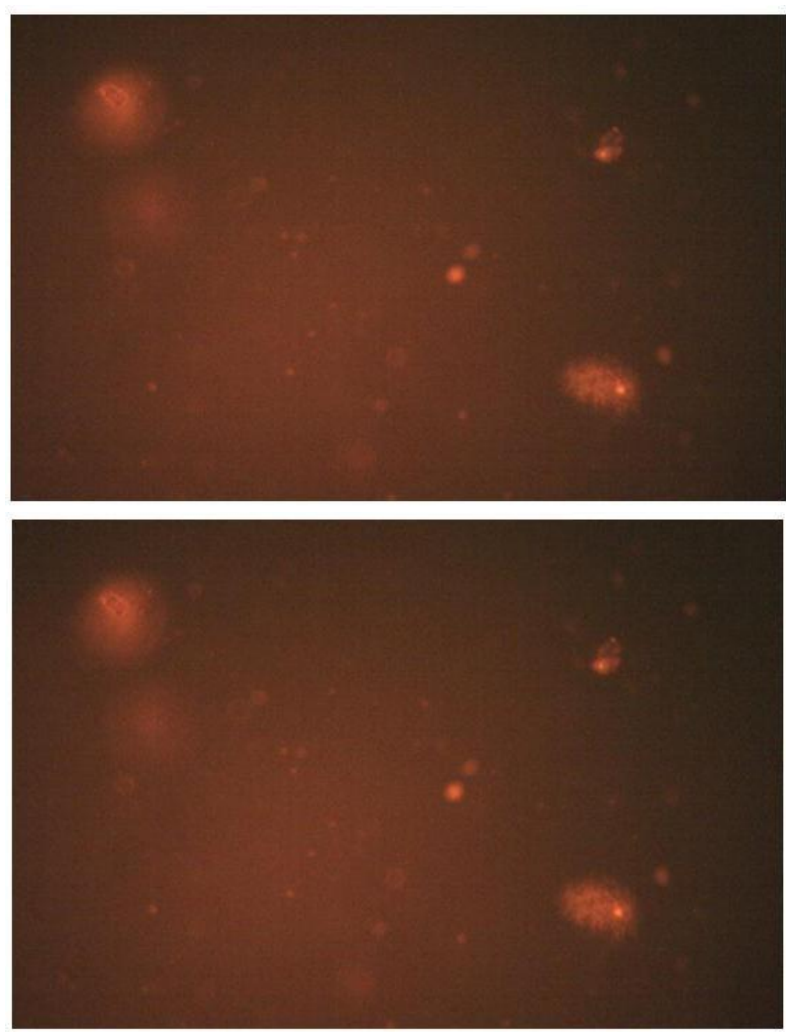

Fig.2A: The Positive Cell Results: The increase in DNA damage was mostly evidenced by an increase of comet tail 


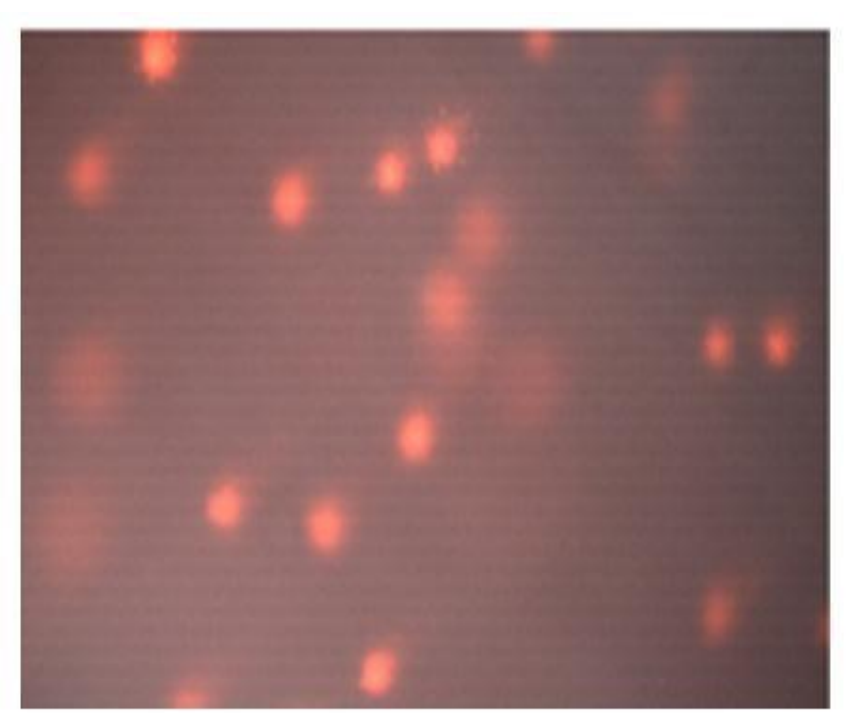

Fig.2B: Normal cell results: DNA is tightly compressed and maintained the circular disposition of normal nucleus

\section{Lymphocyte transformation}

Table 4 shows that (G1) induced significant increase of lymphocyte transformation $2.003 \pm 0.39$ at the $7^{\text {th }}$ day post vaccination, $2.19 \pm 0.17$ on the $10^{\text {th }}$ day post vaccination and $2.65 \pm 0.20$ on the $14^{\text {th }}$ day post vaccination when compared with the vaccinated $(\mathrm{G} 2)$ that recorded significant increase in lymphocyte transformation $1.83 \pm 0.50$ and $2.03 \pm 0.003$ on the $7^{\text {th }}$, $10^{\text {th }}$ day post vaccination and $2.31 \pm 0.17$ on the $14^{\text {th }}$ day post vaccination when compared with vaccinated group (G3).

Table 4: The results of Lymphocyte transformation assay on vaccinated and control heifers

\begin{tabular}{|cccc|}
\hline \multicolumn{4}{c|}{ Days post vaccination } \\
\hline \multirow{2}{*}{ Groups } & $7^{\text {th }}$ day & $10^{\text {th }}$ day & $14^{\text {th }}$ day \\
\hline & 2.003 & 2.19 & 2.65 \\
G1 & \pm & \pm & \pm \\
& $0.39^{\mathrm{a}}$ & $0.17^{\mathrm{a}}$ & $0.20^{\mathrm{a}}$ \\
& 1.83 & 2.03 & 2.31 \\
G2 & \pm & \pm & \pm \\
& $0.50^{\mathrm{b}}$ & $0.003^{\mathrm{a}}$ & $0.17^{\mathrm{a}}$ \\
\hline & 1.72 & 1.78 & 1.92 \\
G3 & \pm & \pm & \pm \\
& $0.14^{\mathrm{c}}$ & $0.24^{\mathrm{b}}$ & $0.11^{\mathrm{b}}$ \\
\hline Control & 1.10 & 1.15 & 1.17 \\
group & \pm & \pm & \pm \\
& $0.02^{\mathrm{d}}$ & $0.027^{\mathrm{c}}$ & $0.13^{\mathrm{c}}$ \\
\hline
\end{tabular}

Means with different superscript letters in the same column are significantly different at $(\mathrm{p}<0.05)$

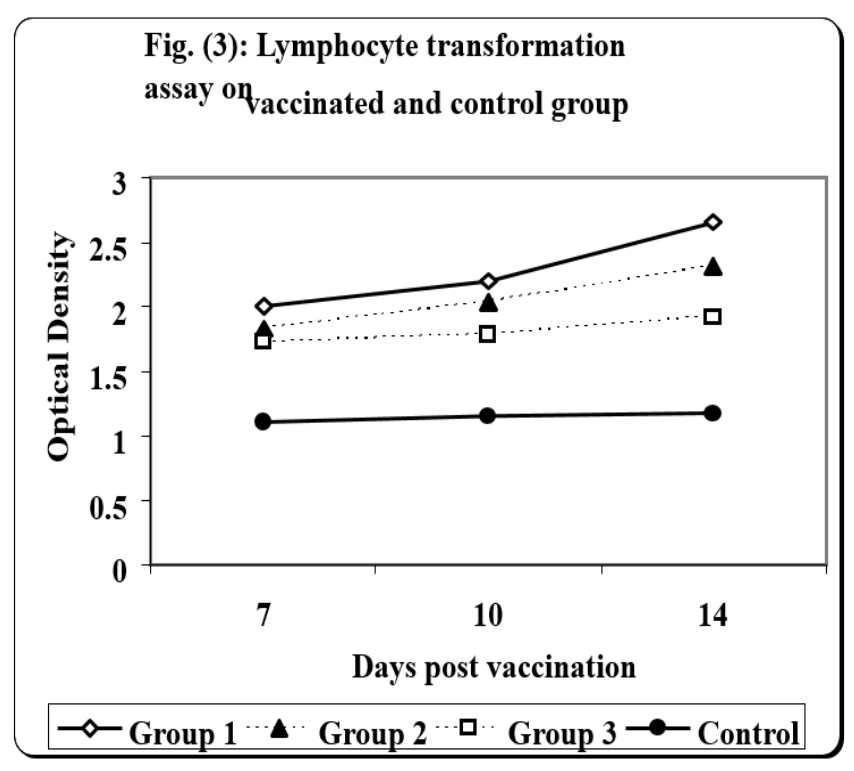

Fig.3: Lymphocyte transformation assay on vaccinated and control group

\section{DISCUSSION}

Common mastitis control measures, have been applied for many years, however, mastitis still remains as one of the most frequent and costly diseases of dairy herds. Vaccination against $S$. aureus mastitis has been studied with very few products making it to market. Kotb (2008) The ideal $S$. aureus mastitis vaccine should either prevent infection or facilitate clearance of the bacteria from the mammary gland very shortly after IMI thus eliminating the possibility of a long-term intramammary infection that can serve as a reservoir for infection of herd-mates. To date, a $S$. aureus mastitis vaccine that meets these criteria has not been developed. Rainard et al., (2018).

Past approaches of vaccine formulation with adjuvants were focused on single-type adjuvants such as alum or emulsions. However, new vaccine targets require the induction of well-defined CMI in addition to high titer of antibody. Consequently, new immunostimulant adjuvants in vaccine formulations are needed in order to stimulate robust immune responses including humoral immunity and CMI. (Lee and Nguyen 2015).

A total of 100 dairy cows were examined for clinical and subclinical mastitis. The results showed that cows with clinical mastitis were exhibited hotness, redness, edema, enlargement and hardness of the affected quarter. This observation is in accordance with that represented by Amer et al., (2018) who observed similar clinical findings of mastitis in Ecuador. CMT is a screening test and considered as rapid and characteristics indicator for detection of subclinical mastitis in dairy fields (Shitandi and Kihumbu, 2004 and Al-Anbari et al., 2006) and the prevalence of subclinical mastitis was $49.8 \%$ nearly close to that recorded in Tanzania and Rwanda by 
Suleiman et al., 2018 and Mpatswenumugabo et al., (2017). About (10-20\%) of cows sampled for bacterial culture based on CMT score will have no growth due to a number of factors including short lived infections that have been cleared by the cow or infections that are characterized by intermittent shedding of bacteria $(S$. agalactiae, S. aureus and Mycoplasma spp.) (Sayed et al. 2015).

The results of the sterility test showed that the prepared vaccines were proved to be free from any extraneous contaminants (aerobic and anaerobic bacteria, mycoplama and fungi). No general adverse reactions to the prepared vaccines were observed in vaccinated or re-vaccinated cows throughout the entire experimental period indicating the safety of the prepared vaccines| (Mella et al. 2017).

ELISA has emerged as a simple important tool for diagnosis as well as monitoring the immune status of animals vaccinated against $S$. aureus vaccine. ELISA, used as a quick technique for detection of antibodies. In this study it was shown that vaccinated heifers had serum antibody titers significantly higher than control animals after first and second immunization Table (2) and Fig. (1). Similar results were obtained by Hogan et al. (2005), Pellegrino et al. (2010) and Perez et al. (2009) who vaccinated cattle with a mineral oil-adjuvanted vaccine and demonstrated a marked serum IgG response.

Adjuvants not only enhance the levels of immune responses, but also have immune modulatory properties that can influence the type and character of induced immune responses. Morein et al., 2004 and Lee and Nguyen 2015

The role of cell-mediated immunity in MG defense has been overshadowed by the traditional focus on toxin-neutralizing and opsonizing antibodies, as exemplified by the absence of cell mediated adaptive immune response section in a recent comprehensive review (Schukken et al., 2011). Currently there is an increasing interest in different $\mathrm{T}$-cell subpopulations contributed to anti-staphylococcal immune defense (Broker et al., 2016).

DNA strand breaks are measured by the comet assay which is an important biomarker of genotoxicity Comet assay is widely used as a simple and sensitive technique for evaluating in vivo, in vitro, and in situ DNA damage in different tissues as gill, liver, kidney, and blood after exposure to different kinds of pollutants or drugs (Dhawan et al.,2009).

In studying (Table 3) DNA integrity of blood cells using comet assay, our results recorded that DNA damage was significantly increase in (G3) which expressed by increase in comet $\%$ and tail moment with non-significant increase in (G1) and (G2) when compared with control group. These results were compatible with Asfour et al., (2016), Genghini et al., (2006) and Maletić et al. (2015) who revealed genotoxic effects of different vaccines by assessing the ability of the vaccine to damage DNA in comet tail with significant increase in cell chromosomal alterations in case of vaccinated animals compared with control one.

The lymphocyte transformation test (LTT) relies on the ability of memory $\mathrm{T}$ cells to proliferate once they have been stimulated by an antigen (Cabañas $\boldsymbol{e t}$ al., 2018). Like other in vitro tests, it is safer than in vivo tests available (Lochmatter et al., 2009). In the present study there was significant increase in lymphocyte transformation after 7,10 and 14 day of immunization in animal vaccinated with montanide ISA 70 and montanide ISA 206 vaccine.

Emulsion of Montanide shown to induce high antibody titer and CTL responses in a variety of animal species. Thus, there are two distinct reasons to incorporate an adjuvant into a vaccine. First as adjuvants are currently used clinically to increase the response to a vaccine in the general population and increasing mean antibody titers and/or the fraction of subjects that become protectively immunized. (Teena et al., 2013).

The results of Montanide ISA 206 and ISA 70 agree with the earlier report of Gamal et al., (2014) and Savoji et al., (2019) who found that the Montanide ISA oil vaccine contains an improved mineral oil enabling the preferential stimulation of Th1-type cellmediated immunity against pathogens of poultry, cattle, and small ruminants.

\section{CONCLUSION}

It can be concluded that $S$. aureus vaccine of Montanide ISA 206 and Montanide ISA 70 adjuvants were able to stimulate the humeral immune response in vaccinated heifers inducing a high level of serum antibodies than alum adjuvant gel vaccine. This could have a beneficial effect on the mammary gland against $S$. aureus new intramammary infections. These results could be indicated the safety and effectiveness of the vaccines in reduction of incidence and severity of clinical cases of mastitis, but further studies should be done to elucidate the possibility of field application and effectively.

\section{Declaration of Competing interest}

On behalf of all authors, I hereby declare that no conflict of interest may interfere with the publication of the manuscript.

\section{REFERENCES}

AL-ANBARI, N.N., ALKASS, J.E. AND AL-RAWI, A.A. .2006. California mastitis test as dependant and independent variable in Holstein cows. The $2^{\text {nd }}$ International Scientific Congress for Environment, South Valley University, Egypt. 
AMER, S., GÁLVEZ, F. L. A., FUKUDA, Y., TADA, C., JIMENEZ, I. L., VALLE, W. F. M., \& NAKAI, Y. 2018. Prevalence and etiology of mastitis in dairy cattle in El Oro Province, Ecuador. Journal of Veterinary Medical Science, 17-0504.

ASFOUR A.E.; ABEER M. ANWER, A.M. NABEEH AND ABEER E. EL-METWALLY. 2016. Some studies on Pasteurella multocida as a causative agent of mastitis in dairy cows and ewes. Assiut Vet. Med. J. Vol. 62 No. 150, 143-156.

BLOWEY R AND EDMONDSON P. 2010. Mastitis control in dairy herds. 2nd ed. CAB International, Wallingford, UK.

BRADLEY, A.J., BREEN, J.E., PAYNE, B., WHITE, V. AND GREEN, M.J. 2015. An investigation of the efficacy of a polyvalent mastitis vaccine using different vaccination regimens under field conditions in the United Kingdom. J. Dairy Sci., 98: 1706-1720.

BROKER, B. M., MROCHEN, D., \& PETON, V. 2016. The $\mathrm{T}$ cell response to Staphylococcus aureus. Pathogens, 5, 31.

BRITISH VETERINARY PHARMACOPOEIA 1993. The Pharmaceutical Press, London

CABAÑAS, R., CALDERÓN, O., RAMÍREZ, E., FIANDOR, A., CABALlero, T., HEREDIA, R. 2018. Sensitivity and specificity of the lymphocyte transformation test in drug reaction with eosinophilia and systemic symptoms causality assessment. Clin. Exp. Allergy 48, 325-333. doi: 10.1111/cea.13076

CHIN, J.; TURNER, B.; BARCHIA, I. AND MULLBACHER, A. 2000. Immune Response to orally consumed antigens and probiotic bacteria. Immunol. Cell Biol., 78 [1], 55-66.

DHAWAN, A., BAJPAYEE, M., \& PARMAR, D. 2009. Comet assay a reliable tool for the assessment of DNA damage in different models. Cell Biology and Toxicology, 25, 5-32.

FERRONATTO J.A., MARLA SCHNEIDER, LINDOMAR F. PESSOA, MAIARA G. BLAGITZ, MARCOS B. HEINEMANN, ALICE M. M. P. DELLA LIBERA AND FERNANDO N. SOUZA 2018. Diagnosing mastitis in early lactation: use of Somaticell , California mastitis test and somatic cell count. Italian Journal OF Animal Science.VOL. 17, NO. 3, 723-729.

GAMAL, W. M., SOLIMAN, E. M. M., \& ELMANZALAWY, M. A. 2014. Tracing the antibody mediated acquired immunity by Foot and Mouth disease and Rift Valley Fever combined vaccine in pregnant ewes and their lambs. Veterinary World, 7(11).

GENGHINI 1,R. I TIRANTI, E BRESSÁN, E ZAMORANO-PONCE，J FERNÁNDEZ， F DULOUT 2006. Determination of genotoxicity of classical swine fever vaccine in vitro by cytogenetic and comet tests. 21(3):213-7.

HOGAN, J.S., CANNON, V.B., SMITH, K.L., RINEHART, C.AND , MILLER, S. 2005. Effects of adjuvants on safety and efficacy of an Escherichia coli J5 bacterin. J Dairy Sci, 88 (2): 534-542.
HOQUE MN, DAS ZC, TALUKDER AK, ALAM MS, AND RAHMAN ANMA 2015. Different screening tests and milk somatic cell count for the prevalence of subclinical bovine mastitis in Bangladesh. Trop Anim Health Prod 2015; 47:79-86.

ISMAIL, Z. B. 2017. Mastitis vaccines in dairy cows: Recent developments and recommendations of application. Veterinary world, 10(9), 1057.

KOTB, E. E. Z. 2008. Some studies on the immune response of lactating bovine mammary gland to different mastitic vaccines. Theises of $\mathrm{PhD}$ degree in vet. Med.Sci. Cairo Univ.

LEE S AND NGUYEN MT. (2015): Recent advances of vaccine adjuvants for infectious diseases. Immune Network ;15(2):51-57.

LEITNER G., YADLIN, B., GLICKMAN, A., CHAFFER, M. AND SARAN, A. 2000. Systemic and local immune response of cows to intramammary infection with staphylococcus aureus. Res. Vet. Sci., 69: 181-184.

LINDBLAD EB. 2004. Aluminium compounds for use in vaccines. Immunol Cell Biol; 82: 497-505.

LOCHMATTER, P., ZAWODNIAK, A., AND PICHLER,W. J. 2009. In vitro tests in drug hypersensitivity diagnosis. Immunol. Allergy Clin. North Am. 29, 537-554.

MALETIĆ, J.; DJELIĆ, N.; RADAKOVIĆ， M ;. MALETIĆ, M.; LAKIĆ, N.; KUKOLJ, V ; ALEKSIĆ, N.; ANDJELKOVIĆ, M. AND STANIMIROVIĆ, Z. 2015. Evaluation of DNA damage in rat lymphocytes expose to tulathromycin in vitro. Genetika, 47, (1): 339-438.

MELLA, A., ULLOA, F., VALDÉS, I., OLIVARES, N., CEBALLOS, A., \& KRUZE, J. 2017. Evaluation of a new vaccine against Staphylococcus aureus mastitis in dairy herds of southern Chile. I. Challenge trial. Austral journal of veterinary sciences, 49(3), 149-160.

MIDDLETON JR, MA J, RINEHART CL, TAYLOR VN, LUBY CD AND STEEVENS BJ. 2006. Efficacy of different Lysigin ${ }^{\mathrm{TM}}$ formulations in the prevention of Staphylococcus aureus intramammary infection in dairy heifers. Journal of Dairy Research, 73 10- 19.

MOREIN B, HU KF AND ABUSUGRA I. 2004. Current status and potential application of ISCOMs in veterinary medicine. Advanced Drug Delivery Review, 56: 1382-1382.

MPATSWENUMUGABO, J. P., BEBORA, L. C., GITAO, G. C., MOBEGI, V. A., IRAGUHA, B., KAMANA, O., \& SHUMBUSHO, B. 2017. Prevalence of subclinical mastitis and distribution of pathogens in dairy farms of Rubavu and Nyabihu districts, Rwanda. Journal of veterinary medicine.

O. I. E,. 2013. Manual of Diagnostic tests and vaccines for terrestrial animals. World Organisation for Animal Health, 1185, 1191. Chapter 1.1.9 Tests for sterility and freedom from contamination of biological materials.

OPDEBEECK, J.P. AND NORCROSS, N.L. L984. Comparative effect of selected adjuvants on the response in the bovine mammary gland to 
staphylococcal and streptococcal antigens. Veterinary Immunology and Immunopathology, 6, 341-351.

PELLEGRINO M, GIRAUDO J, RASPANTI C, ODIERNO L AND BOGNI C. 2010. Efficacy of immunization against bovine mastitis using a Staphylococcus aureus avirulent mutant vaccine. Vaccine, $284523-4528$.

PEREIRA, U.P., OLIVEIRA, D.G.S., MESQUITA, L.R., COSTA, G.M. AND PEREIRA, L.J. 2011. Efficacy of Staphylococcus aureus vaccines for bovine mastitis: A systematic review. Vet. Microbiol., 148: 117-124

PÉREZ, M.M., PRENAFETA, A., VALLE, J.,PENADÉS, J., ROTA, C., SOLANO, C., MARCO, J., GRILLÓ, M.J., LASA, I., IRACHE, J.M., MAIRA-LITRAN, T., JIMÉNEZ-BARBERO, J., COSTA, L., PIER, G.B., ANDRÉS, D. AND AMORENA, B. 2009. Protection from Staphylococcus aureus mastitis associated with poly- $\mathrm{N}$-acetyl beta-1,6 glucosamine specific antibody production using biofilm embedded bacteria. Vaccine, 27(17): 23792386.

QUINN, P.J.; MARKEY， B.K.; CARTER, M.E.; DONELLY, W.J. AND LEONARD, F.C. 2003. Veterinary Microbiology and Microbial Disease. Can Vet J., 44 (12): 986.

RAINARD, P., FOUCRAS, G., FITZGERALD, J. R., WATTS, J. L., KOOP, G., and MIDDLETON, J. R. 2018. Knowledge gaps and research priorities in Staphylococcus aureus mastitis control. Transboundary and emerging diseases, 65 , 149-165.

SAN MARTÍN B, KRUZE J, MORALES MA, AGÜERO H, AND LEÓN B. 2002. Bacterial resistance of mastitis pathogens isolated from dairy cows in the Vth Region, Metropolitan Region, and Xth Region, Chile. Arch Med Vet 34, 221-234.

SAVOJI, M. A., HAGHIGHAT, S., MIRZAEE, M., GOLKARAN, B., MIRZAEE, R., ESFANDIARI, B., and MAHDAVI, M. 2019. Formulation of HBs antigen in Montanide ISA266 shows superiority to commercial $\mathrm{HBsAg}$ vaccine in the induction of humoral immune responses. Gastroenterology and hepatology from bed to bench, 12(4), 292.

SAYED, M.L., SHELL, W.S., HANAN, A. AHMED, HANAN, M. IBRAHIM, NASR, E.A. AND ALI, A.M. 2015. Efficacy of a locally prepared bovine mastitis vaccine. Benha Veterinary Medical Journal, Vol. 29, No. 2: 309-318.

SCHALM OW, NOORLANDER DD. 1957. Experiments and observations leading to development of the California Mastitis Test. J Am Vet Med Assoc. 130:199-204

SCHUKKEN, Y. H., GÜNTHER, J., FITZPATRICK, J., FONTAINE, M. C., GOETZE, L., HOLST, O., \& SMITH, D. G. E. 2011. Host-response patterns of intramammary infections in dairy cows. Veterinary immunology and immunopathology, 144(3-4), 270-289.
SCHUKKEN, Y.H., BRONZO, V., LOCATELLI, C., POLlERA, C., ROTA, N., CASULA, A., TESTA, F., SCACCABAROZZI, L., MARCH, R., ZALDUENDO, D., GUIX, R. AND MORONI, P. 2014. Efficacy of vaccination on Staphylococcus aureus and coagulase-neg-ative Staphylococci intramammary infection dynamics in 2 dairy herds. J. Dairy Sci., 97 : 5250-5264.

SHITANDI, A. AND KIHUMBU, G. 2004. Assessment of the California mastitis test usage in small holder dairy herds and risk of violative antimicrobial residues. J. Vet. Sci. 5: 5-9.

SINGH, N.P., MCCOY, M.T., TICE, R.R. AND SCHNEIDER, E.L. 1988. A simple technique for quantification of low levels of DNA damage in individual cells. Exp. Cell Res., 175: 184.

SNEDECOR,G.W. AND COCHRAN,W.G.(1982): Statistical methods. $7^{\text {th }} \quad$ Edition, The Iowa State University Press, Iowa

SULEIMAN, T. S., KARIMURIBO, E. D., \& MDEGELA, R. H. 2018. Prevalence of bovine subclinical mastitis and antibiotic susceptibility patterns of major mastitis pathogens isolated in Unguja island of Zanzibar, Tanzania. Tropical animal health and production, 50(2), 259-266.

THAKER HC, BRAHMBHATT MN AND NAYAK JB. 2013. Isolation and identification of Staphylococcus aureus from milk and milk products and their drug resistance patterns in Anand, Gujarat, Vet World 6(1):10-13.

TEENA MOHAN, PRIYANKA VERMA \& D. NAGESWARA R.A.O. 2013. Novel adjuvants \& delivery vehicles for vaccines development: A road ahead Indian J Med Res 138, November 2013, pp 779-795.

TONG C., WU, Z., YU, L., FAN, Z., CHEN,L., HU, R., MA, J., SONG, B., ZHU, Z. AND CUI, Y. 2014. Development of an indirect ELISA for detection of E. coli antibodies in cow serum using a recombinant OmpT as antigen. J. Immunoassay Immunochem. 35(3): 241-255.

WANG X, MENG J, ZHANG J, ZHOU T, ZHANG Y, YANG B, ET AL. 2012. Characterization of Staphylococcus aureus isolated from powdered infant formula milk and infant rice cereal in China. Int. J Food Microb.; 153:142-7.

WATSON, D.L. 1992. Vaccination against experimental staphylococcal mastitis in dairy heifers. Res. Vet. Sci., 53:346.

WATSON, D.L., MCCOLL, M.L. AND DAVIES, H.I. 1996. Field trial of a staphylococcal mastitis vaccine in dairy herds: clinical, subclinical and microbiological assessments. Aust. Vet. J., 74: 447450 .

How to cite this article:

Ebtsam E.Z. Kotb, Amal M. EL Sawah, Laila E. Kortam, Ola A. Abd El Fattah, Waleed M. Barghooth, 2021. Evaluation Of Using Different Adjuvants Used For Preparation Of Staphylococcus Aureus Mastitis Vaccine On The Immune Response. Journal of Applied Veterinary Sciences, 6(1): $9-17$.

DOI: https://dx.doi.org/10.21608/javs.2021.140065 